The Frequency of Muscle Protein Polymorphism in Menidia menidia (Atherinidae) along the Atlantic Coast

Raymond P. Mohgan II and Nancy I. Ulanowicz

Reprinted from Copeis, 1976, No. 2, May 17 pp. 356-360

Made in United States of America

UMCEES Ref. No. 76-105 CBL 


\title{
The Frequency of Muscle Protein Polymorphism in Menidia menidia (Atherinidae) along the Atlantic Coast
}

\author{
Raymond P. Morgan II and Nancy I. Ulanowicz
}

Electrophoretic separation of the soluble muscle proteins from the Atlantic silverside (Menidia menidia L.) revealed three phenotypes (Mu $A A, A B$ and $B B$ ) postulated to be genetically controlled by two codominant alleles, independent of the sex and size of the fish. The frequency, $\mathrm{Mu}^{\mathrm{A}}$, of the fastest migrating phenotype differed among samples collected from 11 localities along the Atlantic coast. Phenotypes of the muscle protcins are related to body depth of the Menidia.

$\mathrm{T}^{\mathrm{H}}$ HE Atlantic silverside, Menidia menidia (Atherinidae), ranges from Florida to Nova Scotia (Kendall, 1902). It is an important forage fish throughout its range for striped bass (Merriman, 1941).

$M$. menidia menidia and $M$. menidia notata are the two recognized subspecies (Kendall, 1902). Subspecies menidia is the southern form, whereas notata is the northern form. Intergradation between the two is at a maximum in the Chesapeake region but intergrades are found almost throughout the entire species range (Kendall, 1902).

Previous work by the senior author disclosed two muscle-protein phenotypes in $M$. menidia. We present the results of a study on the frequency of the muscle protein polymorphism in populations along the Atlantic coast and the relation of the polymorphism to the subspecies.

\section{Materials and Methods}

Juvenile and adult specimens were obtained by beach seining over a three-month period (in
1972) from Il locations along the Atlantic (Fig. 1). Identification as $M$. menidia was based on meristic charactcristics and scale morphology (Bayliff, 1950). The fish wcre stored on ice and frozen until assayed. For each fish, sex and fork length were recorded. Menidia collected during 1973 and 1974 were also checked for sex. In addition to measuring fork lengths, two other measurements were madc. One was the distance from the snout to the first dorsal fin and the other was the depth of the body posterior to the head and anterior to the first dorsal fin at the greatest body depth (no ripe females were used for these measurements). These measurements were used to obtain ratios of first dorsal position and body depth relative to the overall length of a fish.

The epaxial muscle mass from gill slit to first dorsal fin was removed, macerated in an equal volume of distilled water, and sonified (Bronwill Biosonik IV) for $1 \mathrm{~min}$ to further liberate any soluble muscle proteins. After low speed centrifugation, $25 \mu$ liters of the supernatent was 


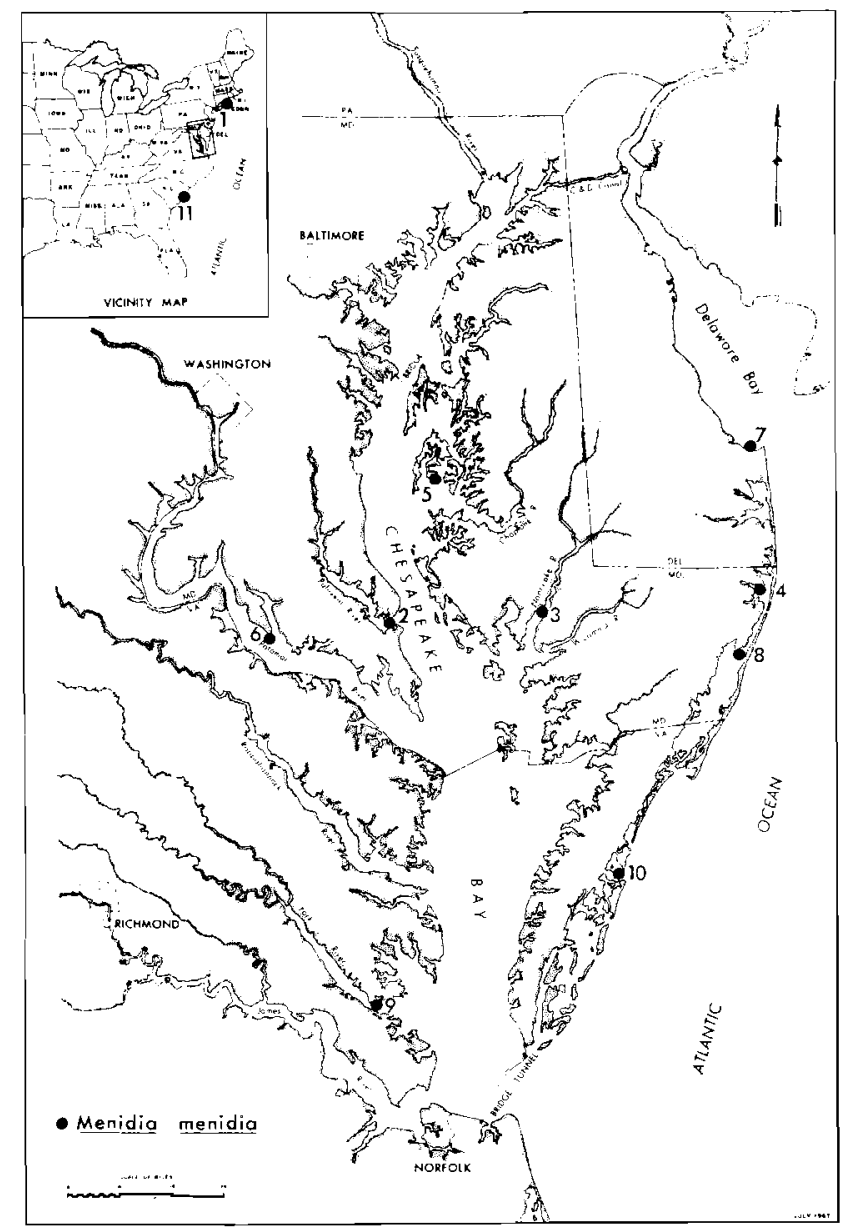

Fig. 1. Station locations for Menidia menidia collections along the Atlantic coast. The numbers correspond to those in Table 1.

used for electrophoresis. Muscle protein applied to each column, as determined by an A/O TS refractometer, was maintained between $200-400$ $\mu$ grams.

Soluble muscle proteins were separated electrophoretically on $8 \%$ acrylamide gels (Davis, 1964) with a Canalco Model 1200 bath and a Beckman Duostat power supply. The acrylamide gels were formed in glass tubes $(7 \mathrm{~mm}$ O.D., $5 \mathrm{~mm} \mathrm{I.D.,} 67 \mathrm{~mm}$ long). The $25 \mu$ liter sample was separated at room temperature (20$23 \mathrm{C})$ with a tris $(0.005 \mathrm{M})$-glycine $(0.039 \mathrm{M})$ buffer, $\mathrm{pH}$ 8.3. The buffer was discarded after each run. A few drops of bromophenol blue $(0.005 \% \mathrm{w} / \mathrm{v})$ solution were added to the buffer prior to electrophoresis. Electrophoresis was terminated when the dye band had migrated to within $5 \mathrm{~mm}$ of the gel end. A constant d-c current of $4.2 \mathrm{~mA} /$ gel was applied to the system; voltage varied from $300-410 \mathrm{~V}$ initially to 220 $340 \mathrm{NV}$ at completion of the electrophoresis.

After the gel was removed from the glass tube, the front edge of the dye band was cut. The cut end of the gel allowed measurements of relative mobility. The protein stain used was $0.1 \%$ Buffalo Black NBR in 7\% acetic acid. Gels were stained for a minimum of $\mathrm{l} \mathrm{hr}$ and the stain was discarded. Destaining of gels was done in a Canalco Quick Gel Destainer with $7 \%$ acetic acid. Gels were stored in $7 \%$ acetic acid in $10 \times 75 \mathrm{~mm}$ culture tubes following destaining.

A chi-square test was used to test the relationship between observed and expected HardyWeinberg phenotypic distributions in $M$. 


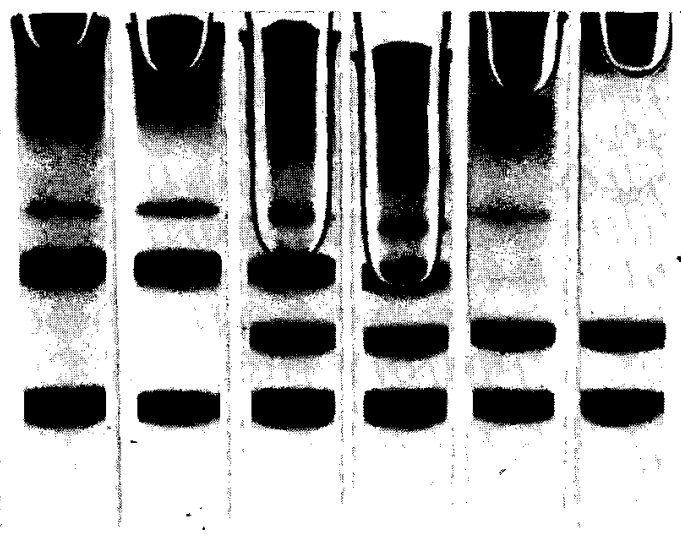

Fig. 2. Acrylamide gels showing the three muscle protein phenotypes in Menidia menidia. From left to right, phenotype $\mathrm{Mu} B B, B B, A B, A B, A A$ and $A A$. The fastest moving dark band is common to all of the polymorphic inuscle protein patterns.

menidia. Other statistical procedures followed Sokal and Rohlf (1969).

\section{Results}

Electrophoretic separation of soluble muscle proteins from $M$. menidia reveals three phenotypes (Fig. 2). These phenotypes are Mu $A A$, the fast migrating homozygote; $\mathrm{Mu} A B$, the heterozygote; and $M u B B$, the slow migrating homozygote (Fig. 2). Phenotypic expression of the muscle protein polymorphism is based on two codominant autosomal alleles since only three phenotypes are observed and the phenotypic distributions did not deviate significantly from the expectcd distribution. The observed phenotypic distribution for the eleven localities corresponds closely to the expected distribution as calculated assuming a Hardy-Weinberg equilibrium (Table 1). Gene frequencies (of $\mathrm{Mu}^{\mathrm{A}}$ ) range from 0.31 at Great Peconic Bay, N. Y., the northernmost station, to 0.98 at Murrells Inlet, S. C., the southernmost station (Table 1 and Fig. 1).

There is no significant relationship of the observed phenotype to sex-male, female or immature ( $\mathrm{G}=7.85,4 \mathrm{df}, \mathrm{ns})$. Also, there is no significant relation ( $\mathrm{G}=1.37,2 \mathrm{df}$, ns) between phenotype and length (less than $75 \mathrm{~mm}$ or greater than $75 \mathrm{~mm}$ ) of the Menidia. In the case of Menidia, $75 \mathrm{~mm}$ is used as a break-off between young-of-the-year and one-year or older fish (Bayliff, 1950).

The relationship of phenotype to body measurements of Menidia is tested by one-way analyses of variance with unequal sample size (Sokal and Rohlf, 1969). First, there is no rela: tion of phenotype to the ratio obtained wher the distance from the snout to the first dorsal fin is divided by the total length. $F$ value of $0.4^{\circ}$ (2.63 $\mathrm{df}$ ) is obtained for this ratio with pheno. type Mu $A A$ having a mean value of $0.473, A R$ of 0.481 and $B B$ of 0.478 . Second, there is a highly significant relationship of the muscle protein phenotype to the ratio of the bodt depth divided by the total length $(F=60.4 ; 2$ $63 \mathrm{df}$ ). Testing of the means through use of the Student-Newman-Keuls test indicates that each phenotype is significantly (at $p<0.05$ ) different from each other. Table 2 summarizes the body depth ratio measurements. In addi. tion. analyses of variance for the relationship of body measurement ratios to sex by phenotype are all insignificant at $\mathrm{p}>0.05$.

Menidia from Murrells Inlet, S. C. (Table $\mathrm{l}$ and Fig. l) are different in body measure. ments than the Chesapeake sample. The dorsal fin ratio is greater $\langle\overline{\mathrm{x}}=0.507, \mathrm{SD}=0.0118$. $\mathrm{CV}=2.34 \%, \mathrm{n}=12$ ) and the body depth ratio is larger $(\overline{\mathrm{x}}=0.165, \mathrm{SE}=0.00617, \mathrm{CV}=3.74 \%$. $\mathrm{n}=12$ ). All of the fish are phenotype Mu $A A$ Menidia collected from near Duxbury, Massachusetts are also different from the Chesapeake sample. The dorsal fin ratio is smaller $(\overline{\mathbf{x}}=$ $0.470, \mathrm{SD}=0.0107, \mathrm{CV}=2.28 \%, \mathrm{n}=16$ ) and the body depth ratio is slightly smaller $(\overline{\mathrm{x}}=$ $0.142, \mathrm{SD}=0.00336, \mathrm{CV}=2.37 \%, \mathrm{n}=16$. All of the Menidia in this sample are phenotype $\mathrm{Mu} B B$.

\section{Discussion}

The muscle protein polymorphism observed in $M$. menidia is similar to that found in Catostomus catostomus (Tsuyuki et al., 1967), Anoplopoma fimbria (Tsuyuki and Roberts, 1969), Sebastodes elongatus (Tsuyuki et al., 1968), and Stizostedion vitreum vitreum (Uthe and Ryder, 1970). Polymorphisms in soluble muscle proteins of fish are rare (Uthe and Ryder, 1970). Up to 1971 , the above four species are the only examples of a muscle protein polymorphism in fish even though a large number of species had been examined (primarily northern species, and primarily by Canadian investigators). So far, all muscle polymorphisms appear to be controlled by only two codominant autosomal alleles at one locus.

The muscle protein polymorphism in $M$. menidia may also be important regarding the two subspecies. Distinguishing characters for M. m. menidia, the southern subspecies, are the 
Table 1. The Distribution of Phenotypes and $A$ Allele (Mun) Frequency in Menidia menidia Muscle ву Locality. The chi-square values were not significant at the $5 \%$ level with one degree of freedom. $(O=$ observed, $\mathbf{E}=$ expected). The numbers in parentheses following the location refer to Fig. 1.

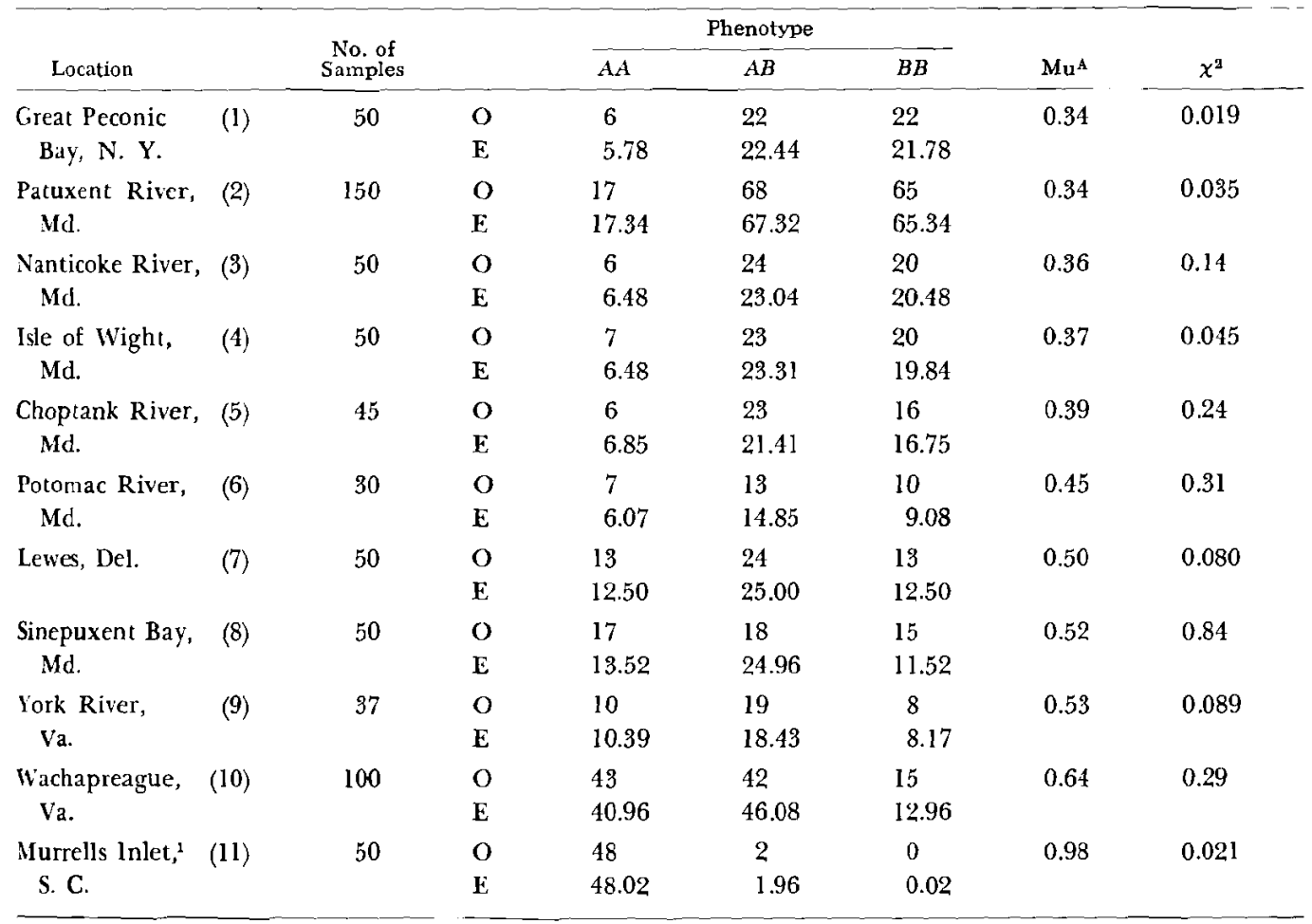

1 Testing of this population violates the assumptions of the chi-square distribution due to one cell being zero.

more posterior position of the first dorsal fin, fewer longitudinal and cross series scales, and deeper body (Kendall, 1902). Kendall (1902) notes that intergrades of the two subspecies appear over a wide area from Woods Hole, Mass. to North Carolina. In Chesapeake Bay, the distinctness of these characters breaks down and intergrades are most common.

Phenotypic and morphological characteristics of Menidia menidia from the Atlantic Coast appear to follow a bimodal pattern. The southern subspecies (or geographical population) $M$. $m$. menidia may be characterized as having a more posterior position of the first dorsal fin, a deeper body and a predominance of $\mathrm{MuA}^{\mathrm{A}}$ alleles in the population. In contrast, the northern subspecies $M . m$. notata is described as having a more anterior position of the first dorsal fin, a thinner body, and a predominance of $\mathrm{Mu}^{\mathrm{B}}$ alleles in the population. Kcndall (1902) states that the notata form is most perfect above Cape Cod, the menidia form most per- fect below South Carolina. Intergrades of these two subspecies are at their greatest in the Chesapeake. Our observations on the frequency and pattern of the muscle protein polymorphism in $M$. menidia agree with Kendall's work. The morphological intergradation of the two forms reaches its greatest point in the Chesapeake Bay

Table 2. Body Deptil (Agtually the Ratio of Body Depth Divided by Toral Length) of Menidia by Phenotype. The 66 fish are all from the Patuxent River $\left(\mathrm{Mu}^{\mathrm{A}}=0.394\right)$.

\begin{tabular}{lccc} 
& \multicolumn{3}{c}{ Muscle phenotype } \\
Statistic & $A A$ & $A B$ & $B B$ \\
\hline$\overline{\mathbf{x}}$ & 0.154 & 0.148 & 0.143 \\
$\mathrm{SD}$ & 0.00636 & 0.00830 & 0.00989 \\
$\mathrm{CV}$ & $4.12 \%$ & $5.63 \%$ & $6.93 \%$ \\
$95 \%$ CI & $0.159-0.149$ & $0.151-0.145$ & $0.147-0.138$ \\
$\mathrm{n}$ & 9 & 34 & 23 \\
& & &
\end{tabular}


area (Kendall, 1902), the area where we observed a great deal of variation in $\mathrm{Mu}^{\mathrm{A}}$.

There is a possibility that the $M$. menidia polymorphism is due to an introgression of the two subspecies. Menidia tend to be non-migratory (Hoff, 1972, Robbins, 1969) but limited genetic exchange in coastal areas could occur through larval drift and juvenile movements.

Another possible explanation for the present $M$. menidia polymorphism is genetic isolation in the past. During the last glacial period, $M$. menidia could have become separated into northern and southern populations. Following the glacial recession, ranges of the two populations met and intermingled.

One other point needs to be considered in discussing $M$. menidia. Recently, Platz and Platz (1973) determined that the hemoglobin phenotypes and morphological phenotypes of Rana pipiens were well correlated. We observed that there are morphological characteristics (the body depth of $M$. menidia) associated with a particular muscle protein phenotype.

\section{ACKNOWLEDGMENTS}

We wish to thank Margaret Flowers, Linda Noe, Janet Olmon, Jerry Hardy, David Brownlee, Robert Bertin, Leo Minasian, Rob Kelsey, Henry Zion, Wayne Gordon, Michael Castagna and Victor Kennedy for their assistance in field collections. Frances Younger and Michael Reber prepared the figures for the text. Miss Ulanowicz was supported by the National Science Foundation Undergraduate Research Participation program, grant Gy-10026 to the Chesapeake Biological Laboratory, Center for Environmental and Estuarine Studies, University of Maryland. We especially thank Ted S. Y. Koo, director of the program, for his assistance during the project. This paper is Contribution 632 of the Center for Environmental and Estuarint Studies. University of Maryland.

\section{Literature Cited}

Bayliff, W. M., JR, 1950. The life history of the silverside, Menidia menidia (Linnaeus). Md. Dep. Res. Educ., Chesapeake Biol. Lab. Contr. 90.

Davis, B. J. 1964. Disc electrophoresis-II. Meth. ods and application to human serum proteins Ann. N. Y. Acad. Sci. ]21:404-427.

HoFF, J. G. 1972. Movements of adult tidewates silverside, Menidia beryllina (Cope), tagged in New England waters. Amer. Midl. Natur. 88: 499-502.

KeNDALL, W. C. 1902. Notes on the silversides of the genus Menidia of the East Coast of the United States with descriptions of two new subspecies. Report, U. S. Comm. Fish and Fish. 1901:241-26?.

Platz, J. E., and A. L. Platz. 1973. Rana pipiens complex: Hemoglobin phenotypes of sympatric and allopatric populations in Arizona. Science 179:1334-1336.

RobBins, T. W. 1969. A systematic study of the silversides Membras Bonaparte and Menidia (Linnaeus) (Atherinidae, Teleostei). Unpubl. Ph.D. Thesis, Cornell University.

SOKAL, R. R., AND F. J. Rohlf. 1969. Biometry. Freeman, San Francisco.

TSUYuk1, H., AND E. RoBerts. 1969. Muscle protein polymorphism of sablefish fronı the eastern Pa. cific Ocean. J. Fish. Res. Bd. Canada 26:26332641.

-, R. H. Kerr, J. F. Uthe and L. W. Clarke. 1967. Comparative electropherograms of the family Catostomidae. Ibid. 24:299-304.

, R. H. LOWES, W. HADAWAY AND S. J. WEST. RHEIM. 1968. Contribution of protein electropho. resis to rockfísh (Scorpaenidae) systematics. Ibid. 25:2477-2501.

Uthe, J. F., AND R. A. Ryder. 1970. Regional variation in muscle myogen polymorphism in walleye (Stizostedion vitreum vitreum) as related to morphology. Ibid. 27:923-927.

Chesapeake Biological laboratory, Center for ENvironmental and Estuarine StUdies, UNiversity OF MARYland, SOlomons, Mary LAND 20688. Accepted 3 March 1975. 